\title{
Plant Growth-Promoting Activity and Genetic Diversity of Endophytic Fungi Isolated from Native Plants in Dokdo Islands for Restoration of a Coastal Ecosystem
}

Young-Hyun You', Hyeokjun Yoon', Hyun Kim', Sung Hwan Lim², Jae-Ho Shin', In-Jung Lee', Yeon-Sik Choo ${ }^{2}$ and Jong-Guk Kim ${ }^{1}$.

${ }^{1}$ School of Life Science, Kyungpook National University, Daegu 702-701, Korea

${ }^{2}$ Department of Biology, College of National Sciences, Kyungpook National University, Daegu 702-701, Korea

${ }^{3}$ School of Applied Biosciences, Kyungpook National University, Daegu 702-701, Korea

Received October 22, 2012 /Revised December 29, 2012 /Accepted January 3, 2013

\begin{abstract}
In this study, plant samples of five species were collected from the Dokdo islands in South Korea. Plant samples such as Asparagus schoberioides, Corydalis platycarpa, Festuca rubra, Sedum oryzifolium, and Setaria viridis were collected from the Dongdo and Seodo. Endophytic fungal strains were isolated from the roots of five plants from the Dokdo islands. Thirty-three fungal strains were isolated from these native plants. All the endophytic fungi were analyzed by internal transcribed spacer (ITS) sequencing (ITS containing ITS1, 5.8s, and the ITS2 region). Waito-c rice seedlings were treated with fungal culture filtrates to test their plant growth-promoting activity. A bioassay of the D-So-1-1 fungal strain isolated from $S$. oryzifolium confirmed that it has the highest plant growth-promoting activity. All the endophytic fungi belong to four orders: Eurotiales $(86 \%)$, Capnodiales $(3 \%)$, Hypocreales $(4 \%)$, and Incertae sedis (7\%). The endophytic fungi were classified as Ascomycota, which contained Aspergillus (12\%), Cladosporium (3\%), Eurotium (3\%), Fusarium (18\%), Microsphaeropsis (6\%), and Penicillium $(58 \%)$ at the genus level.
\end{abstract}

Key words : Dokdo islands, endophytic fungi, diversity, plant growth promotion, phylogenetic analysis

\section{서 론}

독도(Dokdo)는 북서 태평양의 연해인 우리나라 동해에 있 는 울릉분지 북쪽경계에 위치(E $131^{\circ} 52^{\prime} 07^{\prime \prime} / \mathrm{N} 37^{\circ} 14^{\prime} 1$ $\left.2^{\prime \prime}\right)$ 하고 있는 해양성 화산도로 알려져 있다. 독도 근해 해상 은 난류와 한류가 만나 완대류를 형성하고 눈과 비가 오는 날이 많고, 연평균 $12^{\circ} \mathrm{C}$ 의 기온을 나타내고 있으며, 강한 바람 의 영향과 급경사 지역이 대부분을 차지하고 있어서 식물이 서식하기에는 어려운 조건을 가지고 있는 것이 알려져 있다. 독도는 크게 동도와 서도로 구분되고, 주위에89개의 작은 부 속 섬들로 이루어져 있으며, $40^{\circ}$ 이상의 급사면이 $65.4 \%$ 를 이 루고 있다[2,5]. 또한, 독도의 토양환경은 화산활동에 의해서 형성되었고, 매우 건조하고 염분함량이 높으며 광조건 및 유 기영양분이 상당히 부족한 조건을 가지고 있다[16, 18]. 그리고

\footnotetext{
*Corresponding author

Tel : +82-53-950-5379, Fax : +82-53-955-5379

E-mail : Kimjg@knu.ac.kr

This is an Open-Access article distributed under the terms of the Creative Commons Attribution Non-Commercial License (http://creativecommons.org/licenses/by-nc/3.0) which permits unrestricted non-commercial use, distribution, and reproduction in any medium, provided the original work is properly cited
}

독도는 온난 다습한 기후이며, 한반도와는 다른 환경조건으로 인하여 독특한 식물상 및 식물군락이 형성되어 있으며, 독도 는 고유한 생태적 및 경관적 가치에 따라 r문화재보호법」에 의거하여 천연기념물로 지정되어 관리되고 있다. 독도의 식 물상에 대한 연구는 1952년부터 수행되어오고 있으며 $[2,6$, 14-18], 48종의 식물이 자생하고 있는 것으로 보고되고 있다[2, 12, 13]. 그리고 독도의 미생물에 대한 연구는 식물근권세균 (PGPR) 및 신종 미생물에 대한 보고가 높은 지역으로 알려져 있다[2, 6, 21]

내생진균류는 식물의 생장에 중요한 역할을 하는 인자로 알려져 있으며, 내생진균류 중에는 식물의 생장에 관여하는 식물생장호르몬인 gibberellins (GA), auxin (IAA), cytokinin, ethylene, abscisic acid (ABA)등을 생산하는 균주에 대한 연구 가 알려져 있으며 $[1,8,9,11]$, 최근에는 농작물에 대한 연구가 아닌 해양성 환경에 자생하는 해안식물의 영향에 대한 내생진 균류 연구가 조금씩 보고되고 있다[4, 22-24]. 그러나 현재 독 도에 자생하는 식물의 내생진균류 및 균류에 대한 연구는 많 이 알려져 있지 않으며, 최근에 점차적으로 보고되고 있다[22, 23].

본 연구에서는 독도에 자생하고 있는 비짜루(Asparagus schoberioides), 갯괴불주머니(Corydalis platycarpa), 왕김의 털 (Festuca rubra), 땅채송화(Sedum aryzifolium), 그리고 갯강아지 
풀(Setaria viriditi)의 뿌리에 공생 및 상호작용하고 있는 내생진 균류를 분리하고, $\mathrm{rDNA}-\mathrm{ITS}$ 영역을 이용하여 동정하였다 [7, 22]. 그리고 독도 자생식물들의 뿌리로부터 분리된 내생진균 류들이 가지는 식물생장촉진활성을 검정하고, 이들 내생진균 류들에 대한 유연관계를 확인하여 계통수를 작성하였으며, 유 전학적 다양성을 분석하였다 $[7,9,10,14]$.

\section{재료 및 방법}

\section{식물시료 및 미생물 시료의 준비}

본 연구에서 사용된 식물시료는 독도의 동도와 서도에 자생하는 비짜루(Asparagus schoberioides, plant code: Ask), 갯괴불주머니(Corydalis platycarpa, Cp), 왕김의 털(Festuca rubra, $\mathrm{Fr}$ ), 땅채송화(Sedum oryzifolium, So), 그리고 갯강아 지풀(Setaria viridis, Sv)을 식물시료로 사용하였다(Table 1.). 그리고 독도에 자생하는 5종의 식물뿌리로부터 내생진균류 를 분리하여 미생물시료로 준비하였고, 한국미생물보존센터 (KCCM)로부터 분양받은 Gibberella fujikuroi (KCCM 12329) 균주를 대조구로 사용하였으며, 식물생장촉진활성검정 (Bioassay)을 위하여 식물시료는 $\mathrm{GA}_{1}$ 생합성이 결핍된 난장 이벼 (Waito-c)를 사용하였다.

\section{내생진균류의 분리 및 배양}

독도에서 채집한 식물시료의 뿌리에 토양을 제거하고, 계면 활성제(Tween 80)를 54 분간 2회 처리한 후에 멸균증류수 (Sterile distilled water)로 세척하였다. 그리고 과염소산 (Perchloric acid) $1 \%$ 를 5 분간 2 회 처리한 후에 멸균증류수로 세척하였고, $3 \sim 4 \mathrm{~cm}$ 길이로 절단하여 수분을 제거하였다[17]. 내생진균류의 분리와 배양을 위하여 스트렙토마이신 (Streptomycin, $80 \mathrm{ppm}$ )이 포함되어 있는 hagem minimal $(\mathrm{HM})$ 배지를 사용하였고 $[19,20]$, 식물의 뿌리를 $25^{\circ} \mathrm{C}$ 조건에 서 배양하였다 $[19,21,24]$. 그리고 배양된 식물시료 뿌리의 끝 단면에서 내생진균을 $\mathrm{HM}$ 배지에 획선도말법(Streaking)을 이 용하여 다시 $25^{\circ} \mathrm{C}$ 조건에서 배양하였다. 그리고 potato dextrose agar (PDA)에 계대배양하여 순수 분리하였다 $[9,11,23$, 24]. 식물의 뿌리에서 순수 분리한 내생진균류들을 Czapek's broth $(\mathrm{CB})$ 배지에 7 일 동안, $180 \mathrm{rpm}, 28^{\circ} \mathrm{C}$ 조건으로 진탕배양 (Shake culture) 하였고[22, 24], 내생진균류의 균체(Mycobiont) 를 여과하여 5일 동안 동결건조하여 동정을 위한 시료로 사용
하였다. 그리고 filter paper (Whatman)를 사용하여 배양액을 여과하였다. 그리고 배양액은 bioassay시험을 위하여 7일 동 안 동결건조 후에 30 배 농축하여 사용하였다.

\section{식물생장촉진활성 시험}

식물생장촉진활성을 확인하기 위하여 난장이벼를 사용하 였고, 난장이벼 체내에서의 GA 생합성발현을 억제하기 위하 여 uniconazol $20 \mathrm{ppm}$ 과 스포탁을 24시간 처리하였다. 그리고 발아한 난장이벼를 water agar $(0.6 \%)$ 에 파종하여 식물생장촉 진활성 식물재료로 사용하였다[3,24]. 식물생장촉진활성을 위 하여 난장이벼 유묘의 이엽기 엽액 부분에 내생진균류의 배양 여과액(30배 농축) $10 \mu 1$ 를 처리하여 7일간 유묘의 생장을 확 인하여 지상부길이(Shoot length)와 식물전체길이(Plant length)를 확인하였다[11, 12, 13, 19, 24]. 그리고 통계처리는 실험으로부터 얻어진 결과를 SPSS version 18.0 을 이용하여 일원배치분산분석(ANOVA: one-way analysis of variance)을 이용하여 기술통계 값을 확인하였고, 사후검정은 Duncan's multiple range test (DMRT)의 방법을 사용하여 유의확률 $p<0.05$ 수준에서 비교 분석하도록 하였다 $[3,23,24]$.

\section{Genomic DNA의 추출과 PCR 반응 조건}

동결건조로 인하여 균체에 수분이 승화된 내생진균류의 시 료는 DNeasy Plant mini kit (QIAgen)를 사용하여 genomic $\mathrm{DNA}$ 를 분리 및 추출하였다 $[5,10]$. 그리고 Polymerase Chain Reaction (PCR) 수행을 위한 templete 조건은 $10 \mathrm{mM}$ Tris- $\mathrm{HCl}$ (pH 8.5), $1.5 \mathrm{mM} \mathrm{MgCl} 2,200 \mathrm{nM}$ dNTPs, $40 \mathrm{mM}$ $\mathrm{KCl}, 10 \mathrm{pmol}$ 의 primer와 0.1 unit의 Ex-Taq DNA polymerase (Takara, Japan)를 사용하였다[22, 24]. PCR 조건은 (1 min, $\left.95^{\circ} \mathrm{C}\right)$ predenaturation, $\left(30 \mathrm{sec}, 95^{\circ} \mathrm{C}\right)$ denaturation, $(1 \mathrm{~min}$, 51-54. $\left.5^{\circ} \mathrm{C}\right)$ annealing, $\left(1 \mathrm{~min}, 72^{\circ} \mathrm{C}\right)$ extension, $(35$ cycles $)$ total cycles, $\left(7 \mathrm{~min}, 72^{\circ} \mathrm{C}\right)$ final extension 으로 수행하였다 $[7,24]$. 그리고 PCR반응을 위하여 universal primer인 ITS1 (5'-TCC GTA GGT GAA CCT GCG G-3')과 ITS4 (5'-GGA AGT AAA AGT CGT AAC AAG G-3')를 이용하여 rDNAITS 영역을 증폭하였다 $[8,23,24]$. PCR 산물은 $1.5 \%$ agarose gel에서 전기영동 후, ethidium bromide (EtBr)을 사용하여 20 분 염색 후, UV transilluminator로 전기영동밴드를 확인하여 분석하였다[22, 24]. 그리고 전기영동 단편들은 QIAquick PCR purification kit (Qiagen Inc., Germany)를 사용하여 정제하였

Table 1. Scientific name and geographic coordinates of the five native plants in Dokdo islands

\begin{tabular}{lccc}
\hline Scientific name of plant sample & Plant code & Local & Fungal isolates \\
\hline Asparagus schoberioides Kunth & Ask & Dongdo & 5 \\
Corydalis platycarpa Makino & Cp & Seodo & 6 \\
Festuca rubra L. & Fr & Seodo & 3 \\
Sedum oryzifolium Makino & So & Dongdo & 11 \\
Setaria viridis var. pachystachys & Sv & Seodo & 8 \\
\hline
\end{tabular}


고, 염기서열 결정을 위하여 ABI PRISM BigDye Terminator Cycle Sequencing Kit (PE Biosystems, Foster City, CA, USA) 를 사용하였으며, DNA 단편들은 $\mathrm{ABI} 310 \mathrm{DNA}$ sequencer (Perkin Elmer, Foster City, CA, USA)를 사용하여 내생진균류 들의 염기서열을 결정하였다[16, 23].

\section{내생진균류의 계통관계 및 다양성 분석}

독도 자생식물의 뿌리로부터 분리된 내생진균류의 염기서 열을 ClustalX 프로그램을 사용하여 다중정렬을 수행하였고,
Lasergene 7 프로그램과 BioEdit 프로그램을 사용하여 염기서 열을 정리 및 분석하였다. 내생진균류의 유연관계 분석은 MEGA 4.1 프로그램의 neighbor-joining (NJ) 방법으로 분석 하였다 $[19,24]$. 그리고 내생진균류의 blast결과를 확인하기 위 하여 rDNA-ITS 영역의 염기서열을 $\mathrm{NCBI}$ 의 nucleotide blast 정보와 비교 분석하였다. 그리고 내생진균류의 다양성 분석 을 위하여 균주들의 목(Order)과 속(Genus)을 확인하였고, 다 양성분석을 확인하기 위하여 다양성지수를 나타내는 Shannon's diversity index $(H)$ 를 적용하였으며 $[14,24]$, 독도

Table 2. Plant growth-promoting activity of Waito-c rice seedlings with culture filtrates of endophytic fungi isolated from the roots of native plants in Dokdo islands

\begin{tabular}{|c|c|c|c|}
\hline Fungal isolates & Closest relative based on sequence homology & Similarity $(\%)$ & GenBANK No. \\
\hline D-Ask-1-4 & Penicillium pinophilum SGE75 (JQ776546) & 100 & JX220188 \\
\hline D-Ask-1-4-1 & Fusarium sp. WF150 (HQ130706) & 100 & JX220189 \\
\hline D-Ask-3-3 & Aspergillus niger MUM05.13 (JF838357) & 100 & JX220190 \\
\hline D-Ask-4-4 & Penicillium canescens (AF033493) & 100 & JX220191 \\
\hline D-Ask-5-4 & Aspergillus tubingensis Uf125-1 (JQ693399) & 100 & JX220192 \\
\hline D-Cp-1-2 & Penicillium sp. FF15 (FJ379815) & 99 & JX220193 \\
\hline D-Cp-2-1 & Penicillium waksmanii TR077 (HQ608108) & 99 & JX220194 \\
\hline D-Cp-3-1 & Penicillium sclerotiorum (JN581573) & 99 & JX220195 \\
\hline D-Cp-3-1-1 & Penicillium sp. CNU 100097 (JF772181) & 99 & JX220196 \\
\hline D-Cp-4-1 & Penicillium viticola (AB606414) & 99 & JX220197 \\
\hline D-Cp-7-2 & Penicillium simplicissimum P25 (JN246043) & 99 & JX220198 \\
\hline D-Fr-1-2-1 & Penicillium adametzii (AF034459) & 100 & JX220204 \\
\hline D-Fr-1-2-2 & Penicillium thomii (AF034448) & 100 & JX220205 \\
\hline D-Fr-1-2-3 & Penicillium sp. M738 (GU446645) & 100 & JX220206 \\
\hline D-So-1-1 & Fusarium culmorum (AB586990) & 99 & JX220213 \\
\hline D-So-1-3 & Eurotium niveoglaucum (HE578069) & 100 & JX220214 \\
\hline D-So-1-4 & Fusarium sp. 3 RIRM-2011 (HQ662681) & 100 & JX220215 \\
\hline D-So-2-2 & Penicillium pasqualense (JN617676) & 100 & JX220216 \\
\hline D-So-2-3 & Cladosporium cladosporioides (FR837924) & 99 & JX220217 \\
\hline D-So-3-2 & Microsphaeropsis sp. DoF18 (JQ388263) & 100 & JX220218 \\
\hline D-So-3-3 & Penicillium citrinum S36 (JF266706) & 99 & JX220219 \\
\hline D-So-3-4 & Microsphaeropsis arundinis (EF094556) & 99 & JX220220 \\
\hline D-So-3-5 & Aspergillus tubingensis Uf125-1 (JQ693399) & 100 & JX220221 \\
\hline D-So-4-1 & Fusarium sp. AJH20 (EU605879) & 100 & JX220222 \\
\hline D-So-4-2 & Fusarium sp. WF157 (HQ130713) & 100 & JX220223 \\
\hline D-Sv-1-1 & Penicillium citrinum S36 (JF266706) & 99 & JX220224 \\
\hline D-Sv-1-4 & Fusarium sp. NRRL 52796 (JF740934) & 100 & JX220225 \\
\hline D-Sv-1-5 & Penicillium pasqualense (JN617676) & 100 & JX220226 \\
\hline D-Sv-1-6 & Penicillium sclerotiorum (AF033404) & 98 & JX220227 \\
\hline D-Sv-2-1 & Penicillium viticola (AB606414) & 98 & JX220228 \\
\hline D-Sv-2-6 & Penicillium pinophilum (JQ776546) & 100 & JX220229 \\
\hline D-Sv-3-3 & Penicillium sp. SGLMf44 (GQ377489) & 100 & JX220230 \\
\hline D-Sv-3-5 & Aspergillus tubingensis JP-1 (EU867248) & 100 & JX220231 \\
\hline
\end{tabular}

The $10 \mathrm{ul}$ of lyophilized culture filtrates were treated on the Waito-c rice seedlings. The shoot and plant length of Waito-c rice seedlings were measured after 7 days. According to DMRT, the different letters in a row indicate significant differences. All plants data $(p<0.05)$ are expressed as mean value \pm S.D.

SL: shoot length

PL: plant length

* Negative control (Distilled water)

** Positive control (Wild type G. fujikurol) 
자생식물군에 대한 내생진균류의 다양성지수를 분석 및 확인 하였다.

\section{결과 및 고찰}

\section{식물생장촉진활성 시험}

독도에서 분리된 내생진균류에 의한 식물생장촉진활성검 정은 난장이벼 유묘의 지상부길이와 식물체길이로 확인하였 고, 통계처리는 실험으로부터 얻은 결과를 SPSS program을 이용하였으며, 평균비교분석은 일원배치분산분석을 통하여 결과를 도출하였으며, 사후검정은 DMRT를 통하여 유의확률 $p<0.05$ 수준에서 분석되었다. 그리고 내생진균류의 배양여과 액을 처리한 식물샘플은 Table 3에 a부터 o까지 주석으로 나 타내었다. 그리고 식물생장촉진활성 검정의 실험 결과는 평균 \pm 표준편차로 나타내어 결과를 도출하였다.

본 연구에서는 내생진균류의 식물생장촉진활성을 검정하 기 위하여 bioassay를 5 반복 수행하였고, 땅채송화에서 분리 된 D-So-1-1 [Fusarium culmorum JX220213]의 내생진균이 Waito-c 유묘생장을 많이 촉진하는 것을 확인 할 수 있었다 (Table 2). 땅채송화의 뿌리내부에서 분리된 So-1-1균주의 경 우, 지상부길이는 평균 $10.95 \mathrm{~cm}$ 와 식물체길이는 평균 19.53 $\mathrm{cm}$ 로 확인되었다. 그리고 처리구인 G. fujikuroi와 D-So-1-1균 주를 비교하였을 때, 통계적으로 대조구와 같이 $\mathrm{a}$ 에 해당하는 결과를 확인 할 수 있었다. 그리고 대조구와 처리구에서는 $\mathrm{DMRT}$ 의 사후분석을 확인 하였고, 같은 $\mathrm{a}$ 그룹에 해당하는 것 으로 볼 때, G. fujikuroi와 D-So-1-1균주는 비슷한 식물생장촉 진활성을 가지는 것으로 생각된다.

본 연구에서는 대한민국 천연기념물 및 특정도서 제 1 호로
지정된 독도의 동도와 서도에서 자생하고 있는 비짜루, 갯괴 불주머니, 왕김의 털, 땅채송화, 갯강아지풀의 뿌리내부 내생 진균류들을 분리 및 동정을 수행하였다. 그리고 이들 내생진 균류들이 가지고 있는 식물생장촉진활성을 확인하였고, 분리 된 균주들간의 다양성을 분석하였으며, 식물과 균류들간의 다 양성 지수를 분석하였다. 그리고 본 연구에서는 식물생장촉진 활성이 우수한 D-So-1-1균주를 발굴하였으며, D-So-1-1 균주 를 이용하여 훼손된 해안지역에 적용하여 식물의 녹화 및 식 생의 복원에 응용될 수 있을 것이라 생각된다.

\section{내생진균의 동정 및 계통학적 분석}

독도에 자생하고 있는 5종의 식물의 뿌리로부터 형태적으 로 다른 내생진균류 33 주를 분리하였다. 독도 자생식물 Ask로 부터 5주, Cp로부터 6주, Fr로부터 3주, So로부터 11주, Sv로부 터 8 주의 염기서열을 분석하여 동정을 수행하였으며, NCBI 의 GenBANK로부터 accession No. [JX220188-JX220198, JX220204-JX220206, JX220213-JX220231]를 제공받았다(Table 3).

내생진균류의 계통학적 분석하였을 때, 독도 자생식물인 Ask에서 Eurotiales목(Order)의 Aspergillus속과 Penicillium속 이 확인되었고, Hypocreales목에 속하는 Fusarium속이 확인되 었다. 자생식물 $\mathrm{Cp}$ 로부터 Eurotiales목의 Penicillium속이 확인 되었고, $\mathrm{Fr}$ 에서는 Eurotiales목의 Penicillium속이 확인되었다. So로부터는 Eurotiales목의 Aspergillus속, Eurotium속, Penicillium속이 확인되었고, Capnodiales목에 속하는 Cladosporium속을 확인하였으며, Hypocreales목의 Fusarium 속과 분류체계가 명확하지 않은 Incertae sedis에 속하는 Microsphaeropsis속을 확인하였다. 그리고 독도 자생식물 $\mathrm{Sv}$ 로 부터 Eurotiales목의 Aspergillus속과 Penicillium속이 확인되었

Table 3. The identification of endophytic fungi isolated in Dokdo islands

\begin{tabular}{|c|c|c|c|c|c|}
\hline Fungal isolates & PL & SL & Fungal isolates & PL & SL \\
\hline D.W & $11.53^{\circ} \pm 0.81$ & $4.28^{\mathrm{p}} \pm 0.10$ & D-So-1-3 & $15.75^{\text {cdefg }} \pm 0.55$ & $6.15^{\text {defg }_{ \pm 0}} \pm .45$ \\
\hline Medium & $14.08^{\mathrm{klm}} \pm 0.69$ & $4.90^{\text {nop }} \pm 0.22$ & D-So-1-4 & $17.25^{b} \pm 0.74$ & $6.93^{b} \pm 0.57$ \\
\hline G. fujikuroi & $19.45^{\mathrm{a}} \pm 0.58$ & $11.00^{\mathrm{a}} \pm 0.58$ & D-So-2-2 & $16.38^{\mathrm{bcd}} \pm 0.46$ & $6.38^{\text {bcde }} \pm 0.51$ \\
\hline D-Ask-1-4 & $15.55^{\text {cdefgh }} \pm 0.34$ & $6.10^{\text {defgh }} \pm 0.39$ & D-So-2-3 & $16.28^{\text {cde }} \pm 0.29$ & $6.65^{\mathrm{bcd}} \pm 0.47$ \\
\hline D-Ask-1-4-1 & $15.53^{\text {cdefghi }} \pm 0.61$ & $5.78^{\text {efghijk }} \pm 0.59$ & D-So-3-2 & $15.93^{\text {cdef }} \pm 0.31$ & $6.10^{\text {defgh }} \pm 0.29$ \\
\hline D-Ask-3-3 & $16.43^{\mathrm{bc}} \pm 0.33$ & $6.88^{\mathrm{bc}} \pm 0.51$ & D-So-3-3 & $14.78^{\text {ghijkl }} \pm 0.41$ & $5.43^{\text {hijklmn }} \pm 0.30$ \\
\hline D-Ask-4-4 & $14.55^{\mathrm{hijk}} \pm 0.82$ & $5.50^{\text {ghijklmn }} \pm 0.54$ & D-So-3-4 & $14.83^{\text {ghijk }} \pm 0.90$ & $5.80^{\text {efghij }} \pm 0.42$ \\
\hline D-Ask-5-4 & $16.03^{\text {cde }} \pm 0.43$ & $6.25^{\text {cdef }} \pm 0.26$ & D-So-3-5 & $13.48^{\mathrm{m}} \pm 0.42$ & $5.10^{\mathrm{klmno}} \pm 0.22$ \\
\hline D-Cp-1-2 & $14.53^{\mathrm{hijk}} \pm 0.39$ & $5.58^{\text {fghijklmn }} \pm 0.25$ & D-So-4-1 & $14.08^{\mathrm{klm}} \pm 1.28$ & $5.33^{\mathrm{ijklmno}} \pm 0.50$ \\
\hline D-Cp-2-1 & $14.60^{\mathrm{hijkl}} \pm 0.46$ & $5.83^{\text {efghij }} \pm 0.43$ & D-So-4-2 & $15.40^{\text {cdefghi }} \pm 0.56$ & $6.00^{\text {defghi }} \pm 0.70$ \\
\hline D-Cp-3-1 & $15.43^{\text {cdefghi }} \pm 0.77$ & $6.20^{\operatorname{defg}_{ \pm}} \pm 0.16$ & D-Sv-1-1 & $15.23^{\text {efghij }} \pm 0.57$ & $5.88^{\text {efghij }} \pm 0.36$ \\
\hline D-Cp-3-1-1 & $14.95^{\text {fghijk }} \pm 0.47$ & $5.50^{\text {ghijklmn }_{ \pm 0.57}}$ & D-Sv-1-4 & $15.53^{\text {cdefghi }} \pm 0.49$ & $5.73^{\text {efghijkl }} \pm 0.39$ \\
\hline D-Cp-4-1 & $14.28^{\mathrm{jklm}} \pm 0.60$ & $5.05^{1 \mathrm{lmno}} \pm 0.31$ & D-Sv-1-5 & $14.15^{\mathrm{klm}} \pm 0.94$ & $5.08^{\mathrm{lmno}} \pm 0.28$ \\
\hline D-Cp-7-2 & $15.35^{\text {defghi }} \pm 0.24$ & $5.68^{\text {efghijklm }} \pm 0.39$ & D-Sv-1-6 & $12.43^{\mathrm{n}} \pm 1.19$ & $4.70^{\mathrm{op}} \pm 0.22$ \\
\hline D-Fr-1-2-1 & $13.73^{1 \mathrm{~m}} \pm 0.60$ & $4.88^{\text {nop }} \pm 0.24$ & D-Sv-2-1 & $14.18^{\mathrm{klm}} \pm 0.34$ & $5.00^{\mathrm{mno}} \pm 0.29$ \\
\hline D-Fr-1-2-2 & $13.73^{\mathrm{lm}} \pm 0.74$ & $5.23^{\mathrm{jklmno}} \pm 0.34$ & D-Sv-2-6 & $15.90^{\text {cdef }} \pm 0.81$ & $6.03^{\text {defgh }} \pm 0.78$ \\
\hline D-Fr-1-2-3 & $14.73^{\text {ghijkl }} \pm 0.71$ & $5.25^{\mathrm{jklmno}} \pm 0.34$ & D-Sv-3-3 & $14.48^{\mathrm{ijklm}} \pm 0.19$ & $5.23^{\mathrm{jklmno}} \pm 0.22$ \\
\hline D-So-1-1 & $19.53^{\mathrm{a}} \pm 0.29$ & $10.95^{\mathrm{a}} \pm 0.37$ & D-Sv-3-5 & $15.68^{\text {cdefg }_{ \pm}} \pm 0.33$ & $6.13^{\text {defgh }} \pm 0.24$ \\
\hline
\end{tabular}



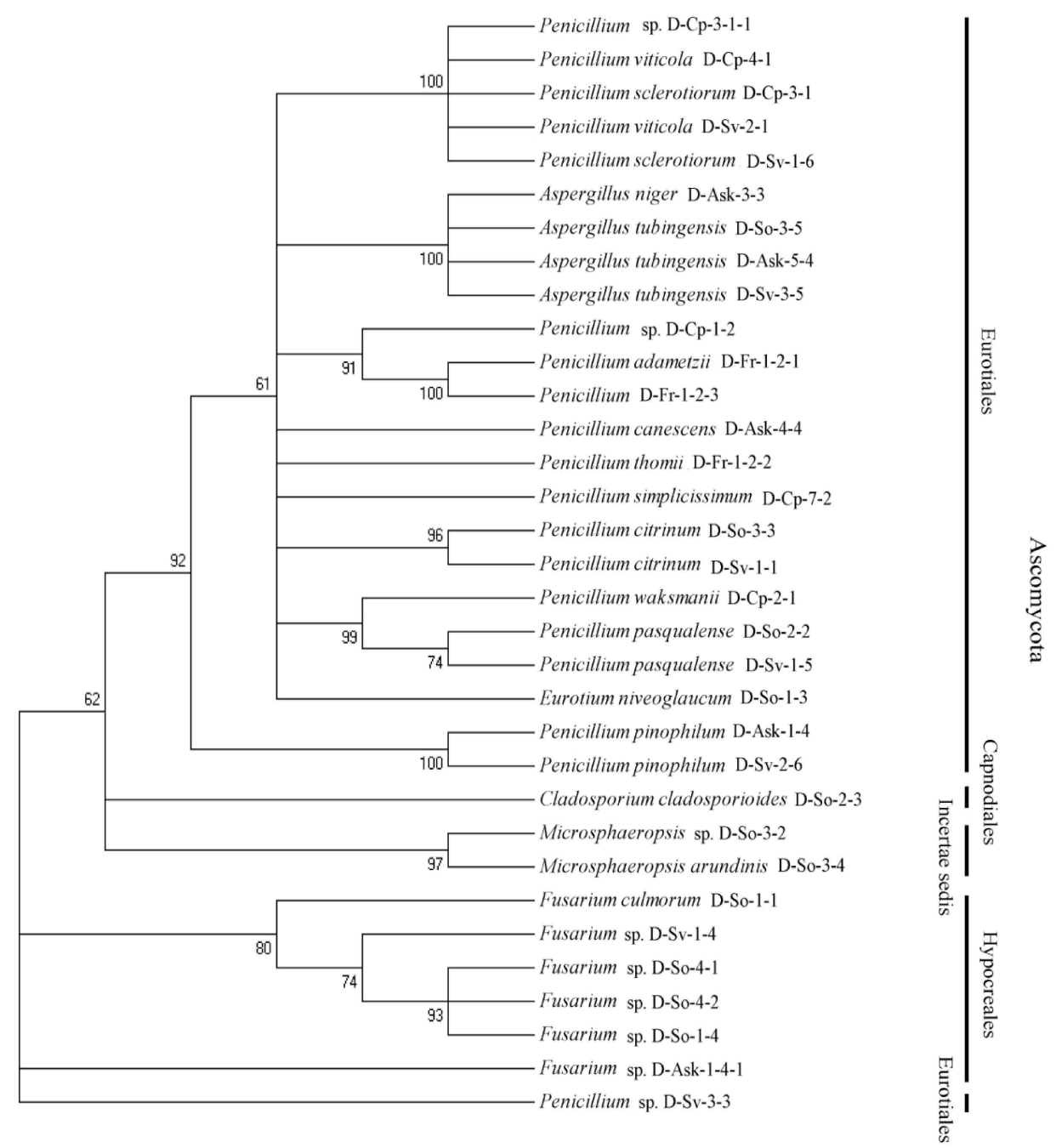

Fig. 1. Phylogenetic analysis of endophytic fungi isolated in Dokdo islands. A phylogenetic tree was constructed using 33 taxa with neighbor joining (1000 bootstrap replications). Phylogenetic tree expressed that all isolated endophytic fungi belong to the genus.

으며, Hypocreales목에 속하는 Fusarium속이 확인되었다. 본 연구에서는 내생진균류들 간의 유연관계를 확인하기 위하여 계통수를 작성하였다(Fig. 1). 그리고 독도에 자생하는 다른 식물들과 비교하였을 때 [22, 23], 자낭균문(Ascomycota)에 속 하는 내생진균류의 비율이 높은 것으로 확인이 되었으며, 본 연구에서도 분리 동정된 내생진균류가 대부분 자낭균문에 속 하는 것을 확인할 수 있었다. 그러나 분류체계가 명확하지 않 은 내생진균류가 확인 되었고, 추가적으로 이들 균류의 연구 가 필요할 것으로 생각된다.

\section{내생진균류의 다양성 분석}

독도에 자생하는 식물들로부터 분리된 내생진균류의 유전 학적 다양성을 확인하기 위하여 Shannon's diversity index를 확인하였다. 분리된 내생진균류는 $\mathrm{Ask}$ 에서 3속 5종, $\mathrm{Cp}$ 에서 1속 5종, $\mathrm{Fr}$ 에서 1속 3종, So에서 6속 8종, Sv에서 3속 7종이
확인되었고, 독도에서 분리된 내생진균류의 목과 속으로 분류 하여 각 분류군에 대한 구성비(\%)를 나타내었다(Table 4). 독 도 자생식물로부터 분리된 내생진균류의 다양성지수는 Ask (1.055), Cp (0.000), Fr (0.410), So (1.642), 그리고 Sv (0.736)으 로 확인되었다(Table 5).

내생진균류는 자낭균문의 Capnodiales목, Eurotiales목, $\mathrm{H}$ ypocreales목에 속하는 다양한 내생진균류들이 분포하는 것을 확인 할 수 있었고, 분리된 모든 균류는 3목6속으로 확인되었 다. 독도에서 분리된 내생진균류의 다양성 지수는 So에서 분 리된 내생진균류의 다양성 지수가 1.642 로 가장 높았고, $\mathrm{Cp}$ 에 서 분리된 내생진균류의 다양성 지수가 0.000 으로 가장 낮은 수치인 것을 알 수 있었다. 그리고 독도에 자생하는 식물 5종 으로부터 미생물 다양성지수를 확인 하였을 때, So (1.642)에서 내생진균류의 다양성지수가 가장 높은 지수로 나타났으며, 분 리식물 중에서 So의 뿌리 내생진균류가 미생물의 다양 
Table 4. Composition of all endophytic fungi isolated from five plants in Dokdo islands

\begin{tabular}{cclc}
\hline Phylum & Order & \multicolumn{1}{c}{ Genus } & $\begin{array}{c}\text { Distribution } \\
\text { ratio (\%) }\end{array}$ \\
\hline \multirow{5}{*}{ Ascomycota } & Eurotiales & $\begin{array}{l}\text { Aspergillus } \\
\text { Eurotium }\end{array}$ & 12 \\
& & Penicillium & 3 \\
& Capnodiales & Cladosporium & 38 \\
& Hypocreales & Fusarium & 18 \\
& Incertae sedis & Microsphaeropsis & 6 \\
\hline
\end{tabular}

The table expressed that all isolated fungal strains belong to the phylum, order and genus level (\%).

Table 5. Diversity index and distribution of endophytic fungi isolated from the five native plants in Dokdo islands

\begin{tabular}{lccccc}
\hline Fungal taxonomic & Ask & $\mathrm{Cp}$ & $\mathrm{Fr}$ & So & Sv \\
\hline Aspergillus & 2 & & & 1 & 1 \\
Cladosporium & & & & 1 & \\
Eurotium & & & & 1 & \\
Fusarium & 1 & & & 4 & 1 \\
Microsphaeropsis & & & & 2 & \\
Penicillium & 2 & 6 & 3 & 2 & 6 \\
Total & 5 & 6 & 3 & 11 & 8 \\
Diversity Index & 1.055 & 0.000 & 0.410 & 1.642 & 0.736 \\
\hline
\end{tabular}

Shannon's diversity index $(H)$ on genus level of endophytic fungi isolated from native plants collected in Dokdo islands were analyzed.

성이 가장 풍부하다는 것을 확인 할 수 있었다.

우리나라의 다른 해안지역이며 람사르습지로 알려진 무안 갯벌에 자생하는 염생식물의 내생진균류들과 비교하였을 때 [25], 무안갯벌은 Acremonium속, Alternaria속, Aspergillus속, Aureobasidium속, Cephalosporium속, Chaetomium속, Cladosporium 속, Colletotrichum속, Cryptococcus속, Didymella속, Dothideomycete 속, Emericellopsis속, Epicoccum속, Eupenicillium속, Fusarium속, Gibberella속, Gongronella속, Macrophoma속, Microsphaeropsis속 등의 다양한 내생진균류들이 확인이 되었으며[25], 독도와는 지리적인 환경 차이에 때문에 다른 미생물상이 나타나는 것을 확인 할 수 있었으며, 독도의 내생진균류에 대한 정보를 보다 더 많이 확인 할 필요가 있다고 생각된다[23].

본 연구에서는 우리나라 독도에 자생하는 식물과 공생하는 내생진균류의 분포 및 다양성을 확인하였고, 이들 균류의 식 물생장촉진활성을 검정하였다. 그리고 본 연구를 토대로 다른 응용 연구 및 분류체계가 명확하지 않은 내생진균류의 연구가 필요할 것으로 생각되며, 염 농도가 높은 환경을 가지는 독도 환경에 대한 균류연구에 기초자료가 되고자 한다.

\section{감사의 글}

본 연구는 환경부 '차세대 에코이노베이션 기술개발사업'
으로 지원 받은 과제이며, 연구비 지원에 감사 드립니다.

\section{References}

1. Clay, K. and Holah, J. 1999. Fungal endophyte symbiosis and plant diversity in successional fields. Science 285, 1742-1744.

2. Ham, M. S., Park, Y. M., Sung, H. R., Sumayo, M., Ryu, C. M., Park, S. H. and Ghim, S. Y. 2009. Characterization of rhizobacteria isolated from family Solanaceae plants in Dokdo island. Kor J Microbiol Biotechnol 37, 110-117.

3. Hasan, H. A. 2002. Gibberellin and auxin-production by plant root-fungi and their biosynthesis under salinity-calcium interaction. Acta Microbiol Immunol Hung 49, 105-118.

4. Hwang, J. S., You, H. Y., Bae, J. J., Khan, S. A., Kim, J. G. and Choo, Y. S. 2011. Effects of endophytic fungal secondary metabolites on the growth and physiological response of Carex kobomugi Ohwi. J Coastal Res 27, 544-548.

5. Jeon, Y. G. 2005. The regional geomorphology of Dokdo (Volcanic Island). Kor J Reg Geol 11, 19-28.

6. Kim, M. H., Oh, Y. J., Kim, C. S., Han, M. S., Lee, J. T. and $\mathrm{Na}, \mathrm{Y}$. E. 2007. The Flora and Vegetation Distribution in Dokdo. Kor J Environ Agric 26, 85-93.

7. Khan, S. A., Hamayun, M., Rim, S. O., Lee, I. J., Seu, J. C., Choo, Y. S., Lee, I. J., J, Kim, S. D., Lee, I. K. and Kim, J. G. 2008. Isolation of endophytic fungi capable of plant growth promotion from monocots inhibited in the coastal sand dunes of Korea. J Life Sci 18, 1355-1359.

8. Khan, S. A., Hamayun, M., Kim, H. Y., Yoon, H. J., Lee, I. J. and Kim, J. G. 2009. Gibberellin production and plant growth promotion by a newly isolated strain of Gliomastix murorum World J Microbiol Biotechnol 25, 829-833.

9. Khan, S. A., Hamayun, M., Yoon, H. J., Kim, H. Y., Suh, S. J., Hwang, S. K., Kim, J. M., Lee, I. J., Choo, Y. S., Yoon, U. H., Kong, W. S., Lee, B. M. and Kim, J. G. 2008. Plant growth promotion and Penicillium citrinum BMC Microbiol $8,231$.

10. Khan, S. A., Hamayun, M., Kim, H. Y., Yoon, H. J., Seo, J. C., Choo, Y. S., Kil, Y. J., Eo, J. K. and Eom, A. H. 2009. Molecular identification and diveristy of endophytic fungi isolated from Pinus densiflora in Boeun, Korea. Kor J Mycol 37, 130-133.

11. Khan, S. A., Hamayun, M., Kim, H. Y., Yoon, H. J., Seo, J. C., Choo, Y. S., Lee, I. J., Kim, S. D., Rhee, I. K. and Kim, J. G. 2009. A new strain of Arthrinium phaeospermum isolated from Carex kobomugi Ohwi is capable of gibberellin production. Biotechnol Lett 31, 283-287.

12. Lee, D. B. and Joo, S. U. 1958. Reinvestigation of the flora of the Dagelet Island. Humani Sci Nat Sci 3, 223-296.

13. Lee, D. H., Cho, S. H. and Pak, J. H. 2007. The analysis of vascular plant species composition in Dok-do island. Kor J Plant Taxon 37, 545- 563.

14. Park, S. J., Song, I. G., Park, S. J. and Lim, D. O. 2010. The Flora and Vegetation of Dokdo Island in Ulleung-gun, Gyeongsanbuk-do. Kor J Env Eco 24, 264-278. 
15. Research Institute for Ullengdo \& Dokdo Islands. 2008. pp.166-221, The plant of Dokdo island. Nature of Dokdo island. Kyungpook National University Press. Daegu. Korea.

16. Seo, S. T., Kim, K. H., Kim, M. J., Hong, J. S., Park, J. H. and Shin, S. C. 2009. Diversity of fungal endophytes from Pinus koraiensis leaves in Korea. Kor J Mycol 37, 108-110.

17. Sun, B. Y., Sul, M. R., Im, J. A. Kim, C. H. and Kim, T. J. 2002. Evolution of endemic vascular plants of Ulleungdo and Dokdo in Korea - floristic and cytotaxonomic characteristics of vascular flora of Dokdo. Kor J Plant Taxon 32, 143-158.

18. Shin, H. T., Park, S. J., Kang, K. H. and Yoo, J. H. 2004. The establishment of conservation area and conservation strategy in Ulnung Island. Kor J Env Eco 18, 221-230.

19. Vazquez, M., Cesar, M., Azcon, S. R. and Barea, J. M. 2000. Interaction between arbuscular mycorrhizal fungi and other microbial inoculants (Azospirillum, Pseudomonas, Trichoderma) and their effects on microbial population and enzyme activities in the rhizosphere of maize plants. Appl Soil Ecol 15, 261-272.

20. Yamada, A., Takeo, O., Yosuke, D. and Masatake, O. 2001. Isolation of Tricholoma matsutake and T. bakamatsutake cultures from field-collected ectomycorrhizas. Mycoscience 42,
43-50.

21. Yoon, J. H., Kang, S. Y., Lee, M. H. and Oh, T. K. 2005. Virgibacillus dokdonensis sp. nov., isolated from a Korean island, Dokdo, located at the edge of the East Sea in Korean. Int J Syst Evol Microbiol 51, 1079-1086.

22. You, Y. H., Yoon, H., Lee, G. S., Woo, J. R., Shin, J. H., Lee, I. J., Rim, S. O., Choo, Y. S. and Kim, J. G. 2011. Diversity and plant growth-promotion of endophytic fungi isolated from the roots of plants in Dokdo islands. J Life Sci 21, 992-996.

23. You, Y. H., Yoon, H., Woo, J. R., Seo, Y., Kim, M., Choo, Y. S. and Kim, J. G. 2011. Plant growth-promoting activity of endophytic fungi isolated from the roots of native plants in Dokdo islands. J Life Sci 21, 1619-1624.

24. You, Y. H, Yoon, H. Kang, S. M., Shin, J. H., Choo, Y. S., Lee, I. J., Lee, J. M. and Kim, J. G. 2012. Fungal diversity and plant growth promotion of endophytic fungi from six halophytes in Suncheon Bay. J Microbiol Biotechnol 22, 1550-1557.

25. You, Y. H., Yoon, H., Seo, Y., Kim, M., Kang, M. S., Kim, C., Ha, S. C., Cho, G. Y. and Kim, J. G. 2012. Genetic diversity of culturable endophytic fungi Isolated from halophytes naturally growing in Muan salt marsh. J Life Sci 22, 970-980.

\title{
초록 : 해안 생태계의 복원을 위하여 독도에 자생하는 식물로부터 분리된 내생진균류의 식물생장촉진활 성과 유전학적 다양성
}

\author{
유영현 ${ }^{1} \cdot$ 윤혁준 $^{1} \cdot$ 김 현 ${ }^{1}$ 임성환 ${ }^{2} \cdot$ 신재호 $^{3} \cdot$ 이인중 ${ }^{3} \cdot$ 추연식 $^{2} \cdot$ 김종국 $^{1}$ * \\ ( ${ }^{1}$ 경북대학교 생명과학부, ${ }^{2}$ 경북대학교 생물학과, ${ }^{3}$ 경북대학교 응용생명과학부)
}

본 연구에서는 독도에 자생하는 5 종의 식물, 비짜루, 갯괴불주머니, 왕김의 털, 땅채송화, 갯강아지풀을 채집하 였다. 독도의 자생식물 뿌리로부터 33 주의 내생진균을 분리하였다. 분리된 모든 내생진균류들은 ITS1, 5.8s와 ITS2를 포함하는 ITS영역의 서열에 의해 분석되었다. 그리고 내생진균류의 배양여과액을 이용하여 난장이벼 유 묘에 처리하여 식물생장촉진활성을 확인하였다. 그 결과, 땅채송화로부터 분리된 D-So-1-1 내생진균이 가장 우수 한 식물생장촉진활성을 나타내었다. 그리고 분리된 모든 내생진균는 자낭균문의 Eurotiales $(86 \%)$, Capnodiales (3\%), Hypocreales $(4 \%)$, 및 Incertae sedis $(7 \%)$ 에 속하는 것을 확인하였다. 그리고 내생진균류를 속으로 분류하 였을 때, Aspergillus (12\%), Cladosporium (3\%), Eurotium (3\%), Fusarium (18\%), Microsphaeropsis (6\%), 및 Penicillium $(58 \%)$ 인 것으로 나타났다. 